\title{
Activating a Peroxo Ligand for C-O Bond Formation
}

\author{
M. Pilar del Río, ${ }^{[a]}$ Paula Abril, ${ }^{[a]}$ José A. López, ${ }^{[a]}$ Mariona Sodupe,${ }^{[b]}$ Agustí Lledós, ${ }^{*[b]}$ Miguel A. \\ Ciriano, ${ }^{[\mathrm{a}]}$ and Cristina Tejel ${ }^{\left.{ }^{[a]}\right]}$
}

\begin{abstract}
Dioxygen activation for effective $\mathrm{C}-\mathrm{O}$ bond formation in the coordination sphere of a metal is a long standing challenge in chemistry for which the design of catalysts for oxygenations is slowed down by the complicated -sometimes poorly understoodmechanistic panorama. In this context, olefin-peroxide complexes could be valuable models for the study of such reactions. Herein, we showcase the isolation of rare 'Ir(cod)(peroxide)' complexes (cod $=1,5$-cyclooctadiene) from reactions with oxygen, and then the activation of the peroxide ligand for $\mathrm{O}-\mathrm{O}$ bond cleavage and $\mathrm{C}-\mathrm{O}$ bond formation by transfer of a hydrogen atom through PT/ET reactions to give 2-iradaoxetane complexes and water. 2,4,6Trimethylphenol, 1,4-hydroquinone, and 1,4-cyclohexadiene were used as hydrogen atom donors. These reactions can be key steps in the oxy-functionalization of olefins with oxygen and they constitute a novel mechanistic pathway disclosed for iridium whose full reaction profile is supported by DFT-calculations.
\end{abstract}

Dioxygen-coordination, $\mathrm{O}=\mathrm{O}$ bond cleavage, and $\mathrm{C}-\mathrm{O}$ bond formation represent an attractive sequency of reactions to yield useful oxygenated organic compounds from raw-materials in an environmentally friendly way. ${ }^{[1]}$ Moreover, this strategy is one of nature's choices, in which reductive activation of molecular oxygen at iron(II) cofactors generates high-valent iron-oxo intermediates $(\mathrm{Fe}=\mathrm{O})$ able to insert into unactivated $\mathrm{C}-\mathrm{H}$ bonds. ${ }^{[2]}$ While this strategy requires the managing of four electrons (from $\mathrm{M}+\mathrm{O}_{2}$ to $\mathrm{M}=\mathrm{O}$ ), a smoother one involves reduction of $\mathrm{O}_{2}$ in one-electron to superoxo intermediates. In this case, a further hydrogen atom abstraction (HAA) -to give an hydroperoxide group- provides the thermodynamic force for the $\mathrm{O}-\mathrm{O}$ bond cleavage, as found in several iron $^{[3]}$ and copper $^{[4]}$ enzimes and in reactions of cobalt superoxide complexes with chatecols $^{[5]}$ and TEMPO-H. ${ }^{[6]}$ However, the potentiality of HAA -or alternatively the most general $\mathrm{PCET}^{\left[{ }^{7]}\right.}$ reactions- in 'reactivating' the two-electron reduced $\mathrm{M}-\mathrm{O}_{2}$ adducts (i.e. peroxide compounds) for $\mathrm{O}-\mathrm{O}$ bond excision and further $\mathrm{C}-\mathrm{O}$ bond formation remains still unexplored. In this regard, iridium(I) complexes could be suitable candidates to explore this possibility knowing the high tendency of such complexes to undergo two-electron redox events in their reactions with oxygen Indeed, a large number of iridium peroxide complexes $\left(\mathrm{Ir}^{\mathrm{III}}-\mathrm{O}_{2}\right)$ -most of them having phosphanes, diphosphanes or NHCs as ancillary ligands- have been reported since the outstanding finding of Vaska, ${ }^{[8,9]}$ but only the oxidation of phosphanes and

[a] Dr. M. P. del Río, P. Abril, Dr. López, Prof. Dr. M. A. Ciriano, Dr. C. Tejel

Departamento de Química Inorgánica, Instituto de Síntesis Química

y Catálisis Homogénea (ISQCH), CSIC-Universidad de Zaragoza

Pedro Cerbuna 12, 50009-Zaragoza (Spain)

E-mail: ctejel@unizar.es

[b] Prof. Dr. A. Lledós, Prof. Dr. M. Sodupe

Departament de Química, Universitat Autónoma de Barcelona

Cerdanyola del Vallès, 08193-Barcelona (Spain)

E-mail: agusti@klingon.uab.es

Supporting information for this article is given via a link at the end of the document. carbon monoxide or formic acid have been studied. ${ }^{[8,10}$ ] Moreover, dioxygen compounds with an olefin as co-ligand are very scarce with very few isolated, ${ }^{[11]}$ or 'in situ' characterized examples. ${ }^{[12,13]}$ These complexes that display both coordination of oxygen and olefin to the metal center can be key species to reveal details for the interplay of these ligands leading to the functionalization of olefins through $\mathrm{C}-\mathrm{O}$ bond formation. In this sense, inner-sphere mechanisms are commonly accepted for late transition metals. ${ }^{[1 c, d]}$

Herein we showcase the isolation and full characterization of unusual Ir(cod)(peroxide) complexes (cod =1,5-cyclooctadiene) and an unprecedented further activation of the peroxide ligand leading to $\mathrm{O}-\mathrm{O}$ bond cleavage and $\mathrm{C}-\mathrm{O}$ bond formation through proton transfer/electron transfer reactions.

Exposure of a red colored suspension of [Ir(pic)(cod)] (1, Hpic = picolinic acid $)^{[14]}$ in benzene to an oxygen atmosphere in the presence of 4-methylpyridine (Mepy) gave an orange-brown solid, further identified as the peroxide(olefin) complex $\left[\operatorname{lr}(\right.$ pic $\left.)(\mathrm{cod})\left(\mathrm{O}_{2}\right)\right](2)$, in $79 \%$ isolated yield (Scheme 1).

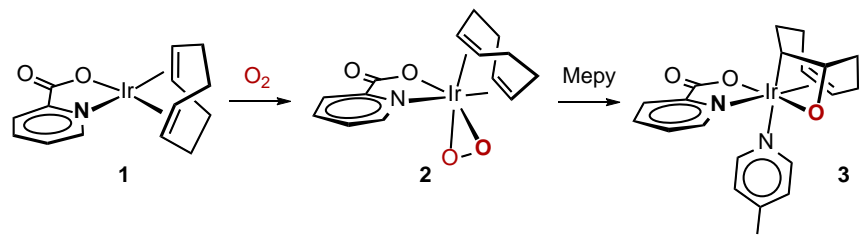

Scheme 1. Synthesis of the peroxide(olefin) complex 2 and the 2-iridaoxetane complex 3.

To our delight, single monocrystals of $\mathbf{2}$ suitable for X-ray diffraction studies ${ }^{[15]}$ resulted from oxygen diffusion into diluted solutions of $\mathbf{1}$ in benzene. According to a formal description of the complex as a $\operatorname{Ir}(\mathrm{III})$-peroxide complex, the structure can be described as an iridium center in a highly distorted octahedral geometry (Figure 1, left). Indeed, the $\mathrm{O}-\mathrm{O}$ bond distance $(1.472(5) \AA)$ lies well within the metal-peroxide category. ${ }^{[16]}$

In addition, the IR-ATR spectrum exhibits a $v\left(\mathrm{O}_{-} \mathrm{O}\right)$ band at $863 \mathrm{~cm}^{-1}$, assignable to a peroxide ligand, ${ }^{[16]}$ which shifts to 815 $\mathrm{cm}^{-1}$ for the isotopologue $\left[\operatorname{Ir}(\mathrm{pic})(\mathrm{cod})\left({ }^{18} \mathrm{O}_{2}\right)\right]\left(2^{\star}\right)$ (calculated value $\left.814 \mathrm{~cm}^{-1}\right)$. Alternatively, the complex can be also described as five-coordinate trigonal bipyramid (TBP) if the dioxygen ligand is assumed to occupy a single coordination site. In agreement with this proposal, the equatorial $\mathrm{C} 1=\mathrm{C} 2$ bond distance is longer than the axial $\mathrm{C} 5=\mathrm{C} 6$, while the metal-centroid Ct1 and Ct2 bond distances follow the opposite trend, as expected for a larger back-donation from the metal in the equatorial plane in TBP-geometries. ${ }^{[17]}$ Accordingly, the olefinic carbons $\mathrm{C} 1$ and $\mathrm{C} 2$ ( $\delta=79.3$ y $78.5 \mathrm{ppm}$ ) were found to be highfield shifted relative to $\mathrm{C} 5$ and $\mathrm{C} 6(\delta=107.4,99.7 \mathrm{ppm}$, Figure 1, right). 

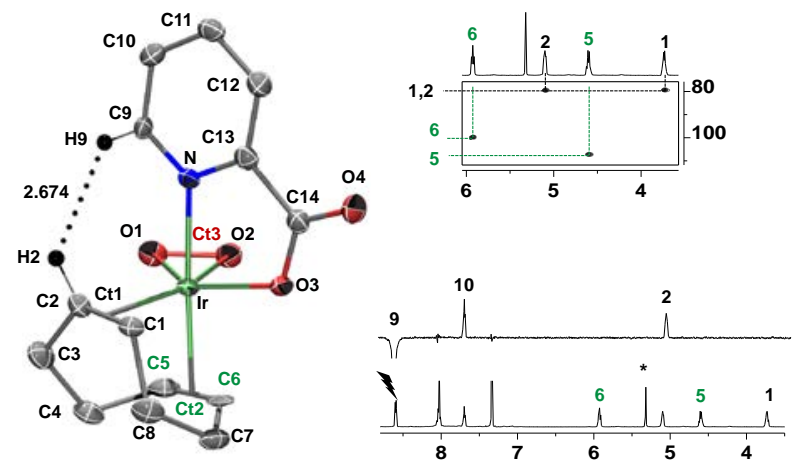

Figure 1. Left: Structure (ORTEP at 50\% level) of the complex $\left[\mathrm{Ir}(\mathrm{pic})(\mathrm{cod})\left(\mathrm{O}_{2}\right)\right]$ (2). Selected bond distances $(\AA)$ and angles $\left({ }^{\circ}\right)$ : Ir-N, 2.065(4); Ir-O1, 1.988(3); Ir-O2, 2.041(4); Ir-O3, 2.098(3); Ir-Ct1, 2.030(5); Ir-Ct2, 2.078(5); O1-O2, 1.472(5); C1-C2, 1.405(6); C5-C6, 1.375(7); $\mathrm{N}-\mathrm{Ir}-\mathrm{Ct} 2,176.3(2) ; \mathrm{O} 3-\mathrm{Ir}-\mathrm{Ct} 1,101.4(2) ; \mathrm{O} 3-\mathrm{Ir}-\mathrm{Ct} 3,122.6(2) ; \mathrm{Ct} 1-\mathrm{Ir}-\mathrm{Ct} 3$ 135.2(2); $\mathrm{Ct} 3$ is the middle point of the $\mathrm{O} 1, \mathrm{O} 2$ bond. Right: Selected regions of the ${ }^{1} \mathrm{H},{ }^{13} \mathrm{C}$-hsqc (top) and of the ${ }^{1} \mathrm{H}$ NMR and selnOe spectra (bottom) in $\mathrm{CD}_{2} \mathrm{Cl}_{2}$ upon irradiation of the proton $\mathrm{H}$, indicated with a ray.

DFT-calculations (TPSSh-D3/BS2 in $\mathrm{CH}_{2} \mathrm{Cl}_{2}$ ) on $\left[\mathrm{Ir}^{\mathrm{III}}(\mathrm{pic})(\mathrm{cod})\left(\mathrm{O}_{2}\right)\right]$ (2) indicate that the peroxide closed-shell singlet species is much more stable than the superoxide redoxomers $\left[\mathrm{Ir}^{\mathrm{II}}(\mathrm{pic})(\operatorname{cod})\left(\eta^{1}-\mathrm{O}_{2}\right)\right]$ in the triplet and open-shell singlet spin sates by +13.8 and $+17.1 \mathrm{kcal} \mathrm{mol}^{-1}$, respectively. The calculated $(\Delta G)$ value for binding of $\mathrm{O}_{2}$ to 1 is $-4.2 \mathrm{kcal}$ $\mathrm{mol}^{-1}$.

Dichloromethane solutions of complex 2 decompose to give insoluble solids and other unidentified products. Nonetheless, a clean transformation of $\mathbf{2}$ into the 2-iridaoxetane complex $\left[\mathrm{Ir}(\mathrm{pic})\left(\mathrm{OC}_{8} \mathrm{H}_{12}\right)(\mathrm{Mepy})\right]$ (3) occurs if 4-methylpyridine (Mepy) is added (Scheme 1, $86 \%$ isolated yield). Noticeably, complex 2 remained unaltered in a more inert solvent such as benzene even in the presence of Mepy. The X-ray molecular structure of 3 shows an uncommon four-membered 2-iridaoxetane ring with an intact $\mathrm{C}=\mathrm{C}$ bond of the former 1,5-cyclooctadiene ligand (Figure 2, left).

The structure of $\mathbf{3}$ shown in Figure 2 is maintained in solution according to NMR spectra. Thus, the signals corresponding to carbons $\mathrm{C} 1$ and $\mathrm{C} 2$ were found at $\delta=0.4$ and $89.7 \mathrm{ppm}$ in the ${ }^{13} \mathrm{C}\left\{{ }^{1} \mathrm{H}\right\}$ NMR spectrum, consistently with their bonding to iridium and oxygen, respectively. In addition, the close proximity of the $\mathrm{H} 1$ and $\mathrm{H} 2$ protons to $\mathrm{H} 9$ was evidenced from the corresponding cross-peaks in the ${ }^{1} \mathrm{H},{ }^{1} \mathrm{H}$-noesy spectrum, whereas the olefinic protons $\mathrm{H} 5$ and $\mathrm{H} 6$ were found to be in close-proximity to the ortho protons of the Mepy ligand ( $\mathrm{H} 15$ and $\mathrm{H} 19$, Figure 2).

Although 2-metallaoxetanes of iridium or rhodium have been known for a long time, ${ }^{[1 d, 18,19]}$ those arising from effective coupling of oxygen with olefins have been rarely observed and represented only by three notable examples: the mononuclear ${ }^{[20]}$ $\left[\operatorname{Ir}\left(\mathrm{OC}_{8} \mathrm{H}_{12}\right)\left(\mathrm{P}_{3} \mathrm{O}_{9}\right)\right]^{2-}$ and the dinuclear ${ }^{[1 \mathrm{1a}, 21]}\left[\left\{\mathrm{Rh}\left(\mathrm{OC}_{8} \mathrm{H}_{12}\right)(\mathrm{L})\right\}_{2}\right](\mathrm{L}$ $=$ diphenyltriazenide, 5,7-dimethyl-1,8-naphthyridin-2-onate) complexes. DFT-calculations indicated that the rhodium(I) precursors react with oxygen to give superoxide complexes $\left(\mathrm{Rh}-\mathrm{O}_{2}{ }^{\circ}\right)$, which are more stable than the corresponding

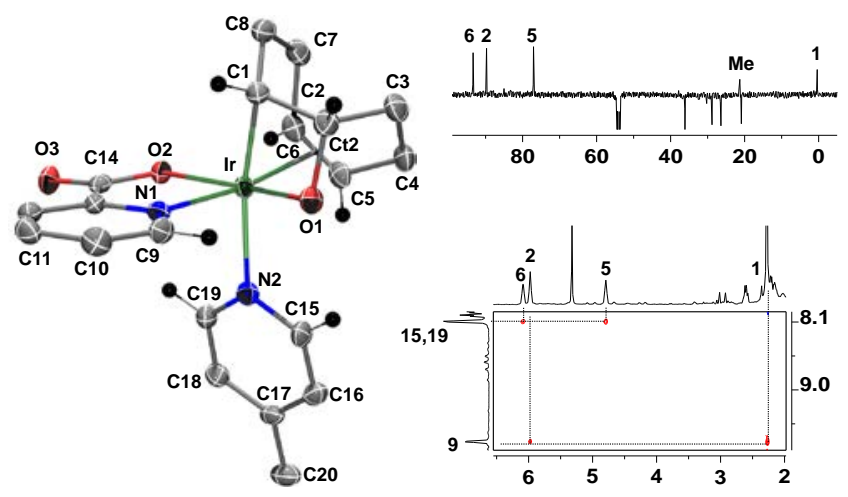

Figure 2. Left: Structure (ORTEP at $50 \%$ level) of the complex [Ir(pic) $\left(\mathrm{OC}_{8} \mathrm{H}_{12}\right)\left(\right.$ Mepy)] (3). Selected bond distances $(\AA)$ and angles $\left({ }^{\circ}\right)$ : Ir-N1, 2.060(4); Ir-N2, 2.224(4); Ir-O1, 2.015(3); Ir-O2, 2.090(3); Ir-C1, 2.046(5); Ir-Ct2, 2.063(5); C1-C2, 1.546(6); C2-O1, 1.456(6); C5-C6, 1.380(7); N2-Ir-C1, 167.3(2); O1-Ir-O2, 166.4(2); N1-Ir-Ct2, 171.6(2). Right: Selected regions of the ${ }^{13} \mathrm{C}\left\{{ }^{1} \mathrm{H}\right\}$-apt (top) and of the ${ }^{1} \mathrm{H},{ }^{1} \mathrm{H}$-noesy (bottom) NMR spectra in $\mathrm{CD}_{2} \mathrm{Cl}_{2}$.

peroxides $\left(\mathrm{Rh}^{\mathrm{III}}-\mathrm{O}_{2}\right)$, and they initiate a dinuclear mechanism for O-O bond cleavage.[1a] A similar mechanism was proposed by Klemperer for the iridium(I) complex. ${ }^{[20]}$ This pathway is unrealistic for the peroxide complex $[\operatorname{Ir}(\mathrm{pic})(\mathrm{cod})(\mathrm{O} 2)](2)$, because the corresponding superoxide redoxomers $\left[\operatorname{Ir}^{\prime \prime}(\mathrm{pic})(\operatorname{cod})\left(\eta^{1}-\mathrm{O}_{2}\right)\right]$ are significantly higher in energy, and consequently, a different mechanism is operative.

Further information about the unprecedented transformation of a peroxide complex into a 2-metallaoxetane compound was gathered with the isotopologue $\left[\operatorname{Ir}(\operatorname{pic})(\operatorname{cod})\left({ }^{18} \mathrm{O}_{2}\right)\right]\left(2^{*}\right)$, which gave $\left[\mathrm{Ir}(\mathrm{pic})\left({ }^{18} \mathrm{OC}_{8} \mathrm{H}_{12}\right)(\mathrm{Mepy})\right]\left(3^{*}\right)$ and $\mathrm{H}_{2}{ }^{18} \mathrm{O}$ in the above reaction in $\mathrm{CH}_{2} \mathrm{Cl}_{2}$ and, in turn, disclosed the abstraction of two hydrogen atoms, most likely from the solvent.

Suspecting the involvement of free-radicals in this reaction, a definitive evidence for the participation of PT/ET reactions in the $\mathrm{O}-\mathrm{O}$ bond cleavage of the peroxo ligand was achieved by using 2,4,6-trimethylphenol (Mesityl-OH) as hydrogen atom donor. Reaction of $\mathbf{2}$ with Mesityl-OH in benzene or dichloromethane and in the presence of Mepy gave the 2-iridaoxetane complex $\left[\operatorname{Ir}\left(\right.\right.$ pic) $\left.\left(\mathrm{OC}_{8} \mathrm{H}_{12}\right)(\mathrm{Mepy})\right]$ (3) as the sole organometallic product. In addition, the clean formation of $\mathbf{3}$ was accompanied by the detection and identification of water, 4-((mesityloxy)methyl)-2,6dimethylphenol (4), and 4-hydroxy-3,5-dimethylbenzaldehyde (5) as by-products (Scheme 2). Furthermore, we verified that the oxygen in $\mathbf{3}$, water, and $\mathbf{5}$ came from the peroxide ligand by ${ }^{18} \mathrm{O}-$ labelled experiments with $\left[\operatorname{Ir}(\mathrm{pic})(\mathrm{cod})\left({ }^{18} \mathrm{O}_{2}\right)\right]\left(2^{\star}\right)$

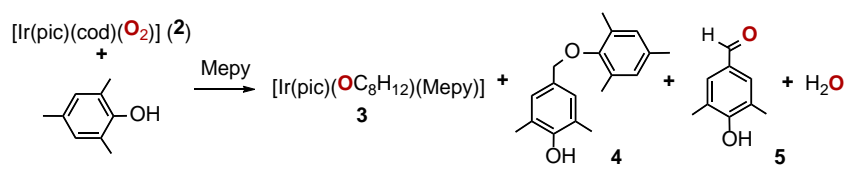

Scheme 2. Reaction of $\left[\operatorname{lr}(\right.$ pic $\left.)(\mathrm{cod})\left(\mathrm{O}_{2}\right)\right](2)$ with Mesityl-OH and Mepy. 
Formation of 4, 5 and water in the above reaction strongly supports the participation of Mesityl-O $0^{\bullet}$ radicals. Thus, the dimer 4 results from the coupling between isomers I and IV of the Mesityl- $0^{*}$ radical, while the aldehyde $\mathbf{5}$ and water would require the participation of the methylendienone $(\mathbf{V})$ and hydroxyl radicals (see below), according to the sequence of reactions shown in Scheme 3.
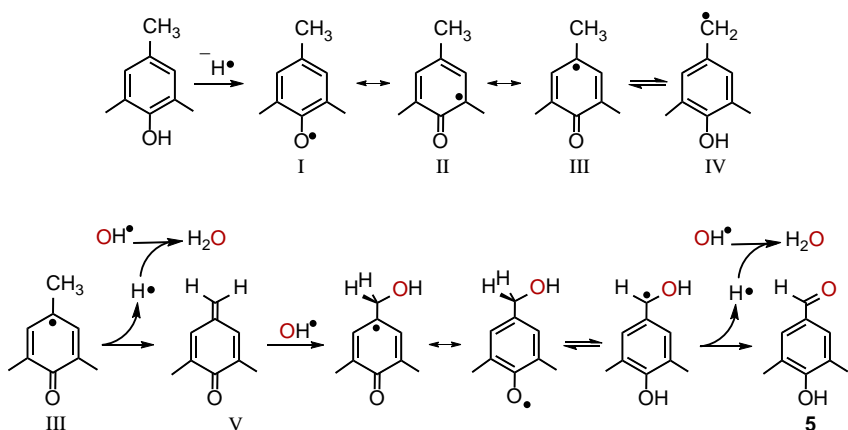

Scheme 3. Canonical forms and isomers of the Mesityl- $0^{\bullet}$ radical (top) and a plausible pathway for the formation of $\mathbf{5}$ and water (bottom).

Moreover, DFT-calculations (TPSSh-D3/BS2 in $\mathrm{CH}_{2} \mathrm{Cl}_{2}$ ) indicated that the formation of both, the dimer $\mathbf{4}$ and the aldehyde 5 and water are exergonic, with $\Delta G=-13.2$ and $-169.3 \mathrm{kcal} \mathrm{mol}^{-1}$, respectively.

With experimental confirmation of the participation of Mesityl- $0^{\circ}$ radicals in hand, it is quite reasonable to propose the radical-pair $\left\{\left[\mathrm{Ir}(\mathrm{pic})(\mathrm{cod})\left(\mathrm{O}_{2} \mathrm{H}\right)(\mathrm{Mepy})\right]^{\circ}\right\}$ Mesityl-O* $\}$ ([A $]^{\circ}$ Mesityl$\left.\mathrm{O}^{\circ}\right)$ as an intermediate resulting from the formal transfer of a hydrogen atom from Mesityl-OH to $\left[\operatorname{Ir}(\mathrm{pic})(\mathrm{cod})\left(\mathrm{O}_{2}\right)\right]$ (2) followed/preceded by the coordination of 4-methylpyridine. The transformation of the (hydroperoxide)iridium radical $\left[\operatorname{Ir}(\text { pic })(\operatorname{cod})\left(\mathrm{O}_{2} \mathrm{H}\right)(\text { Mepy })\right]^{*}\left([\mathrm{~A}]^{*}\right)$ into the products has been studied by DFT methods (TPSSh-D3/BS2 in $\mathrm{CH}_{2} \mathrm{Cl}_{2}$ ) in the doublet potential energy surface (Figure 3 ).

The first step corresponds to the excision of the O-O bond -through a very low-energy transition state (TS1 ${ }^{\circ}$ - to give the intermediate $[\mathbf{B}]^{\circ}$, in which the spin density is evenly located on the iridium and one of the oxygen atoms. A further shift of the unpaired electron from the iridium to the coordinated oxygen bond in TS2 ${ }^{\circ}$ generates an iridium(III)-oxo species, allowing thus the interaction of this oxo oxygen with one carbon of the $\mathrm{C}=\mathrm{C}$ bond. This step ends up with the formation of the $\mathrm{C}-\mathrm{O}$ bond in the intermediate $[\mathbf{C}]^{*}$. Spin density on this intermediate was found to be located only on the oxygen atom of the $\mathrm{OH}$ group (1.00), so that $[\mathrm{C}]^{\circ}$ is indeed the diamagnetic complex $\left[\mathrm{Ir}(\mathrm{pic})\left(\mathrm{OC}_{8} \mathrm{H}_{12}\right)(\mathrm{Mepy})\right]$ (3) and an hydroxyl radical $\left(\mathrm{HO}^{\circ}\right)$. The end of this hydroxyl radical to give water and the aldehyde $\mathbf{5}$ has already been shown in Scheme 3.

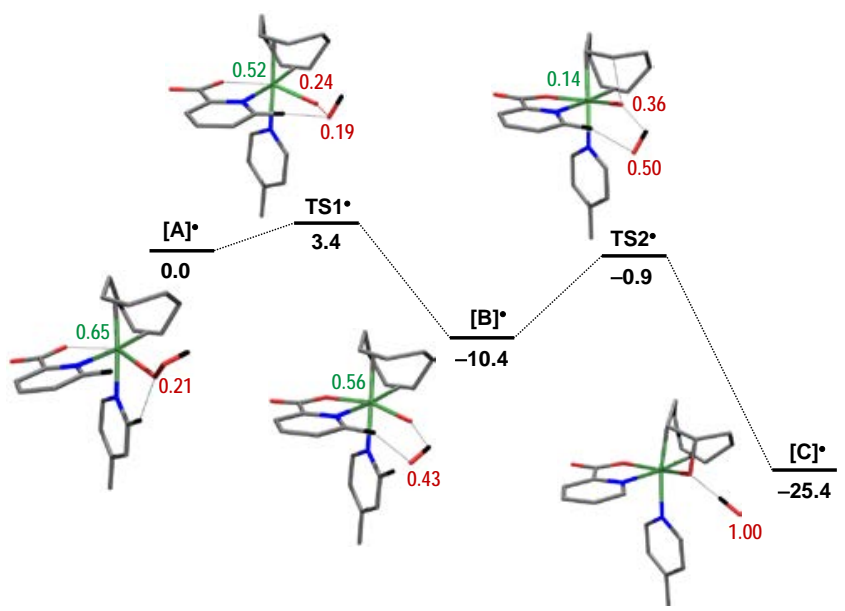

Figure 3. Gibbs energy profile (TPSSh-D3/BS2 in $\mathrm{CH}_{2} \mathrm{Cl}_{2}$ ) in the doublet potential surface for the evolution of the (hydroperoxide)iridium radical $[\mathbf{A}]^{*}$. Values of $\Delta G$ are given in $\mathrm{kcal} \mathrm{mol}^{-1}$. Numbers in green and red denote the spin density on the iridium and oxygen atoms, respectively.

We have computationally studied several alternative pathways for the formation of the (hydroperoxide)iridium radical $\left([\mathrm{A}]^{\circ}\right)$. The most favourable pathway involves a stepwise proton transfer (PT)/electron transfer (ET), with mechanistically distinct PT and ET steps. ${ }^{[22]}$ PT and Mepy coordination occur in the first step, which yields the diamagnetic species $\left\{\left[\operatorname{Ir}(\text { pic })(\mathrm{cod})\left(\mathrm{O}_{2} \mathrm{H}\right)(\mathrm{Mepy})\right]^{+}\right\}$Mesityl-O $\}\left([\mathrm{A}]^{+}[\text {Mesityl-O }]^{-}\right)$, with a barrier of $16.1 \mathrm{kcal} \mathrm{mol}^{-1}$. This ion pair was found to be only 4.2 $\mathrm{kcal} \mathrm{mol}^{-1}$ higher in energy than the starting materials (2+Mepy+Mesityl-OH). The second step is the electron transfer from the Mesityl- $\mathrm{O}^{-}$to the iridium complex to give the radical-pair [A $]^{\circ}$ (Mesityl-O) $)^{\bullet}$, which is $22.9 \mathrm{kcal} \mathrm{mol}^{-1}$ above the ion pair. This step entails spin crossing from the singlet to the triplet potential energy surfaces. We have also analysed the functional dependence of the PT and ET barriers. Computed barriers range from 13.5 to $18.9 \mathrm{kcal} \mathrm{mol}^{-1}$ for the first one (PT), whereas the second one (ET) -related with the change of the spin stateis more dependent on the functional (from 15.8 to $23.3 \mathrm{kcal}$ $\mathrm{mol}^{-1}$, see Supporting Information). Overall, the stepwise PT/ET appears to be a very plausible mechanism for the formation of the $[\mathrm{A}]^{\circ}$ radical.

Notice that oxygen activation mediated by metals requires two steps of different (mainly opposite) nature. First, dioxygen coordinates to the metal; thus its electrophilic character is strongly diminished, and the compound becomes quite inert. Then, a further activation is required for $\mathrm{O}-\mathrm{O}$ bond scission and $\mathrm{C}-\mathrm{O}$ bond formation. In our case, the reactivation is achieved by the formal transference of a hydrogen atom through a PT/ET reactions, which represents a novel pathway for O-O bond activation and $\mathrm{C}-\mathrm{O}$ bond formation.

This approach is not restricted to Mesityl-OH. A similar transformation of $\mathbf{2}$ into the 2-iradoxetane $\mathbf{3}$ was observed by using $p$-hydroquinone as hydrogen atom donor. In this case, the reaction was found to be accomplished with the formation of equimolar amounts of $p$-quinone and water. Moreover, other $\mathrm{H}$ 
atom donors such as 1,4-cyclohexadiene also promotes the reaction, to give complex $\mathbf{3}$ and benzene.

Furthermore, this protocol can be extended to other iridiumperoxide complexes. To substantiate this point, the peroxo formamidinate complex $\left[\operatorname{Ir}(\mathrm{PhNC}(\mathrm{Ph}) \mathrm{NPh})(\mathrm{cod})\left(\mathrm{O}_{2}\right)\right](7,66 \%$ isolated yield) was prepared and isolated as an orange solid by reaction of $[\operatorname{Ir}(\mathrm{PhNC}(\mathrm{Ph}) \mathrm{NPh})(\mathrm{cod})](6)$ with oxygen, and it was fully characterized by analytical and spectroscopic methods. Complex 7 also undergoes the newly developed process, giving the 2-iridaoxetane complex $\left[\operatorname{Ir}(\mathrm{PhNC}(\mathrm{Ph}) \mathrm{NPh})\left(\mathrm{OC}_{8} \mathrm{H}_{12}\right)(\mathrm{Mepy})\right]$ (8, $61 \%$ by ${ }^{1} \mathrm{H}$ NMR) by reaction with Mesityl-OH in the presence of Mepy in benzene (Scheme 4).
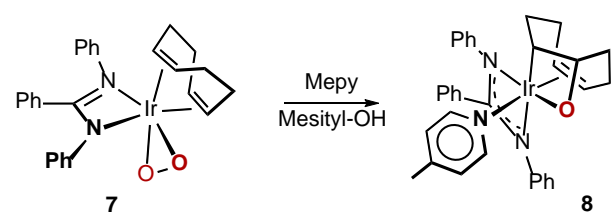

Scheme 4. Synthesis of the 2-iridaoxetane complex 8.

Selective nOe experiments (selnOe) indicate that complex 8 was obtained as the stereoisomer shown in Scheme 4, with the labile nitrogen of the formamidinate ligand placed trans to the carbon $\sigma$-bonded to iridium. Indeed, DFT calculations on complex $\mathbf{8}$ and the related isomer similar to $\mathbf{3}$ (with Mepy trans to the $\sigma-\mathrm{C}$-Ir bond) revealed that the former is $3.9 \mathrm{kcal} \mathrm{mol}^{-1}$ more stable than the later.

In summary, the results reported here show that iridium peroxide complexes can be activated by proton transfer/electron transfer reactions that yield iridium hydroperoxide radicals. If an olefin is coordinated to the metal center such species easily undergo $\mathrm{O}-\mathrm{O}$ bond cleavage and $\mathrm{C}-\mathrm{O}$ bond formation to give 2iridaoxetane complexes. This is a novel mechanistic pathway disclosed for iridium in the oxygenation of olefins. Indeed, DFTcalculations (TPSSh-D3/BS2 in $\mathrm{CH}_{2} \mathrm{Cl}_{2}$ ) of the reaction pathways for other complexes with olefin different from cod, such as 1,4norbornadiene and ethylene give very similar reaction profiles (see Supporting Information).

The reported reactions herein can be key steps in the oxyfunctionalization of olefins with air. Also relevant is the information on the destiny of the second oxygen atom of the coordinated dioxygen, which is intercepted by the $\mathrm{H}$-atom donor (Mesityl-OH, p-hydroquinone, and 1,4-cyclohexadiene) to give water, avoiding thus reactive oxygen species and unselective side-reactions in aerobic oxygenations. The reported findings highlight the potentiality of peroxide intermediates in oxygenation, providing innovative possibilities to enable the design of new and more selective and/or reactive oxygenation catalysts.

\section{Acknowledgements}

The generous financial support from MINECO/FEDER (Projects CTQ2014-53033-P and CTQ2017-83421-P, C.T.; CTQ201787889-P, A.L. and CTQ2017-89132-P, M.S.), and Gobierno de Aragón (GA/FEDER, Inorganic Molecular Architecture Group E08_17R; C.T.) is gratefully acknowledged. M.P.d.R. and P.A. thank MINECO/FEDER for a JdC contract and a FPI fellowship, respectively.

Keywords: Oxygenation • dioxygen cleavage $・$ 2-iridaoxetanes • iridium $\bullet$ peroxide complexes

[1] a) L. Vilella-Arribas, M. García-Melchor, D. Balcells, A. Lledós, J. A López, .S. Sancho, B. E. Villarroya, M. P. del Río, M. A. Ciriano, C Tejel, Chem. Eur. J. 2017, 23, 5232-5243; b) I. Gamba, Z. Codolà, J. Lloret-Fillol, M. Costas, Coord. Chem. Rev. 2017, 334, 2-24; c) C. Tejel, M. A. Ciriano, Top. Organomet. Chem. 2007, 22, 97-124; d) B. de Bruin, P. H. M. Budzelaar, A. W. Gal, Angew. Chem. Int. Ed. 2004, 43, 41424157; Angew. Chem. 2004, 116, 4236-4251.

[2] a) S. C. Peck, C. Wang, L. M. K. Dassama, B. Zhang, Yi. Guo, L. J. Rajakovich, J. M. Bollinger, Jr., C. Krebs, W. A. van der Donk, J. Am. Chem. Soc. 2017, 139, 2045-2052; b) M. Borrell, M. Costas, J. Am. Chem. Soc. 2017, 139, 12821-12829; c) W. N. Oloo, L. Que, Jr. Acc. Chem. Res. 2015, 48, 2612-2621; d) W. Nam, Y.-M. Lee, S. Fukuzumi, Acc. Chem. Res. 2014, 47, 1146-1154; e) K. P. Bryliakov, E. P. Talsi, Coord. Chem. Rev. 2014, 276, 73-96; f) M. Costas, Coord. Chem. Rev. 2011, 255, 2912-2932.

[3] See for example: a) E. Tamanaha, B. Zhang, Y. Guo, W.-C. Chang, E. W. Barr, G. Xing, J. St. Clair, S. Ye, F. Neese, J. M. Bollinger, Jr., C. Krebs, J. Am. Chem. Soc. 2016, 138, 8862-8874; b) W. A van der Donk, C. Krebs, J M. Bollinger, Jr., Curr. Opin. Struct. Biol. 2010, 20, 673-683.

[4] a) C. E. Elwell, N. L. Gagnon, B. D. Neisen, D. Dhar, A. D. Spaeth, G. M. Yee, W. B. Tolman, Chem. Rev. 2017, 117, 2059-2107; b) R. E. Cowley, L. Tian, E. I. Solomon, Proc. Natl. Am. Soc. 2016, 113, 1203512040.

[5] See for example: C. W. Anson, S. Ghosh, S. Hammes-Schiffer, S. S. Stahl, J. Am. Chem. Soc. 2016, 138, 4186-4193 and references therein.

[6] C.-C. Wang, H.-C. Chang, Y.-C. Lai, H. Fang, C.-C. Li, H.-K.i Hsu, Z.-Y. Li, T.-S. Lin, T.-S. Kuo, F. Neese, S. Ye, Y.-W. Chiang, M.-L. Tsai, W.-F. Liaw, W.-Z. Lee, J. Am. Chem. Soc. 2016, 138, 14186-14189.

[7] D. R. Weinberg, C. J. Gagliardi, J. F. Hull, C. F. Murphy, C. A. Kent, B. Westlake, A. Paul, D. H. Ess, D. G. McCafferty, T. J. Meyer, Chem. Rev. 2012, 112, 4016-4093.

[8] See for example: a) H. Baumgarth, G. Meier, T. Braun, B. Braun-Cula, Eur. J. Inorg. Chem. 2016, 4565-4572; b) M. Feller, E. Ben-Ari, Y. Diskin-Posner, R. Carmieli, L. Weiner, D. Milstein, J. Am. Chem. Soc. 2015, 137, 4634-4637; c) C. Schiwek, J. Meiners, M. Förster, C. Würtele, M. Diefenbach, M. C. Holthausen, S. Schneider, Angew. Chem. 2015, 127, 15486-15490; Angew. Chem. Int. Ed. 2015, 54, 15271-15275; d) A. V. Polukeev, O. F. Wendt, Organometallics 2015, 34, 4262-4271; e) H. Baumgarth, T. Braun, B. Braun, R. Laubenstein, R. Herrmann, Eur. J. Inorg. Chem. 2015, 3157-3168.

[9] L. Vaska, Science 1963, 140, 809-810.

[10] See for example: a) S. Dürr, B. Zarzycki, D. Ertler, I. IvanovićBurmazović, U. Radius, Organometallics 2012, 31, 1730-1742; b) W. I. Dzik, J. M. M. Smits, J. N. H. Reek, B. de Bruin, Organometallics 2009, 28, 1631-1643; c) M. A. Ciriano, J. A.López, L. A. Oro, J. J.PérezTorrente, M. Lanfranchi, A. Tiripicchio, M. Tiripicchio-Camellini, Organometallics 1995, 14, 4764-4775.

[11] $\quad\left[\operatorname{IrCl}\left(\mathrm{PPh}_{3}\right)_{2}\left(\mathrm{C}_{2} \mathrm{H}_{4}\right)\left(\mathrm{O}_{2}\right)\right]:$ a) A. van der Ent, A. L. Onderdelinden, Inorg Chim. Acta 1973, 7, 203-208; $\left[\operatorname{lr}(\operatorname{cod})(\text { phen })\left(\mathrm{O}_{2}\right)\right]^{+}$: b) D. J. A. de Waal, T. I. A. Gerber, W. J. Louw, R. van Eldik, Inorg. Chem. 1982, 21, 2002- 
2006; $\left[\operatorname{lr}\left(\mathrm{N}_{3}\right)\left(\mathrm{C}_{2} \mathrm{H}_{4}\right)\left(\mathrm{O}_{2}\right)\right]\left(\mathrm{N}_{3}=\mathrm{Me}_{3}\right.$ tpa, $\left.\left.\mathrm{Me}_{2} \mathrm{dpaMe}\right) ; \mathrm{c}\right)$ B. de Bruin, T. P. J. Peters, J. B. M. Wilting, S. Thewissen, J. M. M. Smits, A. W. Gal, Eur. J. Inorg. Chem. 2002, 2671-2680.

[12] M. R. Kelley, J.-U. Rohde, Dalton Trans. 2014, 43, 527-537 and references therein.

[13] S. Thewissen, D. A. Plattner, B. de Bruin, Int. J. Mass Spec. 2006, 249$250,446-450$

[14] L. Carlton, J. J. Molapisi, J. Organomet. Chem. 2000, 609, 60-65.

[15] CCDC $1859032 \quad\left(2 \cdot 1 / 2 \mathrm{C}_{6} \mathrm{H}_{6}\right)$ and 1859033 (3) contain the supplementary crystallographic data for this paper. These data can be obtained free of charge from The Cambridge Crystallographic Data Centre via www.ccdc.cam.ac.uk/data request/cif.

[16] C. J. Cramer, W. B. Tolman, K. H. Theopold, and A. L. Rheingold, Proc. Natl. Am. Soc. 2003, 100, 3635-3640.

[17] See for example: A. L. Serrano, M. A. Casado, J. A. López, C. Tejel, Inorg. Chem. 2013, 52, 7593-7607.

[18] A. Dauth, J. A. Love, Chem. Rev. 2011, 111, 2010-2047.

[19] 2-Metallaoxetanes of rhodium and iridium from reactions with $\mathrm{H}_{2} \mathrm{O}_{2}$ :a) A. N. Desnoyer, S. Behyan, B. O. Patrick, A. Dauth, J. A. Love, P. Kennepohl, Inorg. Chem. 2016, 55, 13-15; b) A. Dauth, C. Rigling, J. Tsoung, J. A. Love, Chem. Eur. J. 2013, 19, 17180-17191; c) P. H. M. Budzelaar, A. N. J. Blok, Eur. J. Inorg. Chem. 2004, 2385-2391; d) T. Sciarone, J. Hoogboom, P. P. J. Schlebos, P. H. M. Budzelaar, R. de Gelder, J. M. M.vSmits, A. W. Gal, Eur. J. Inorg. Chem. 2002, 457-464; e) B. de Bruin, J. A. W. Verhagen, C. H. J. Schouten, A. W. Gal, D.
Feichtinger, D. A. Plattner, Chem. Eur. J. 2001, 7, 416-422; f) B. de Bruin, M. J. Boerakker, J. A. W. Verhagen, R. de Gelder, J. M. M. Smits, A. W. Gal, Chem. Eur. J. 2000, 6, 298-312; g) T. C. Flood, M. limura, J. M. Perotti, A. L. Rheingold, T. E. Concolino, Chem. Commun. 2000, 1681-1682; h) B. de Bruin, M. J. Boerakker, J. J. J. M. Donners, B. E. C. Christiaans, P. P. J. Schlebos, R. de Gelder, J. M. M. Smits, A. L. Spek, A. W. Gal, Angew. Chem. 1997, 109, 2153-2157; Angew. Chem. Int. Ed. Engl. 1997, 36, 2063-2067;

2-Metallaoxetanes of rhodium and iridium from reactions with halohydrins: h) M. J. Calhorda, A. M. Galvão, C. Ünaleroglu, A. A. Zlota, F. Frolow, D. Milstein, Organometallics 1993, 12, 3316-3325; i) A. A. Zlota, F. Frolow, D. Milstein, J. Am. Chem. Soc. 1990, 112, 6411-6413;

A 2-iridaoxetane from water activation has been recently reported: j) $T$. Ghatak, M. Sarkar, S. Dinda, I. Dutta, S. M. W. Rahaman, J. K. Bera, J. Am. Chem. Soc. 2015, 137, 6168-6171.

[20] V. W. Day, W. G. Klemperer, S. P. Lockledge, D. J. Main, J. Am. Chem. Soc. 1990, 112, 2031-2033.

[21] a) M. P. del Río, M. A. Ciriano, C. Tejel, Angew. Chem. Int. Ed. 2008, 47, 2502-2505; Angew. Chem. 2008, 120, 2536-2539; b) C. Tejel, M. A. Ciriano, E. Sola, M. P. del Río, G. Ríos-Moreno, F. J. Lahoz, L. A. Oro, Angew. Chem. Int. Ed. 2005, 44, 3267-3271; Angew. Chem. 2005, 117 , 3331-3335.

[22] J. M. Mayer, I. J. Rhile, Biochim. Biophys. Acta 2004, 1655, 51-58. 


\section{Entry for the Table of Contents}

\section{COMMUNICATION}

Taming oxygen for effective cleavage of the O-O bond and a further $\mathrm{C}-\mathrm{O}$ bond formation has been achieved through proton transfer/electron transfer protocols. A free radical mechanism accounts for the transformation of peroxide complexes into water and 2-iradaoxetane complexes as shown in the Figure. Code color: Ir (green), O (red), N (blue), C (gray).

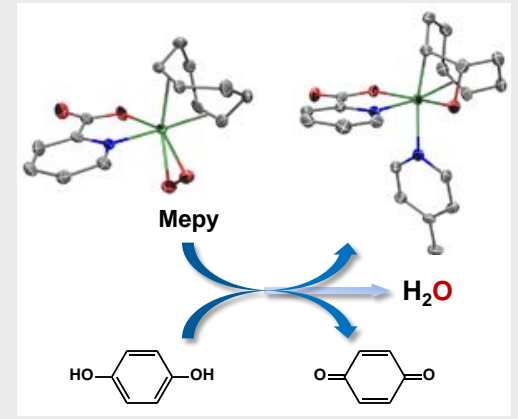

M. Pilar del Río, Paula Abril, José A. López, Mariona Sodupe, Agustí Lledós, * Miguel A. Ciriano, and Cristina Teje/*

Page No. - Page No.

Activating a Peroxo Ligand for $\mathrm{C}-\mathrm{O}$ Bond Formation 